\title{
Complexity as Integration: \\ Pastoral Mobility and Community Building in Ancient Mongolia
}

\section{Jargalan Burentogtokh}

Yale University, New Haven

\section{William Honeychurch}

Yale University, New Haven

\section{William Gardner}

Yale University, New Haven

\begin{abstract}
The question of complex socio-political organization among pastoral nomadic groups has long posed a theoretical challenge for anthropologists, historians, and archaeologists alike. The problems arise from a disciplinary tendency to view pastoralists within a narrow economic and ecological framework but, in addition to this, the basic conception of 'complexity' has itself proven problematic. The definitions of complexity built originally upon systems theory and political economy place emphasis on organizational criteria derived primarily from sedentary societies with class stratification, intensive subsistence economies, and centralized administration. In this paper we argue that these classic definitions of complexity have not provided a good fit for analyzing the kinds of political organizations constructed by pastoral nomads of the Eurasian steppe zone. For that reason, we explore new ways of conceptualizing complex organization based on processes of integration, scale, and mobility. This approach offers a better explanation for material patterns documented across two neighboring valleys in northern Mongolia and provides substantial insight to the sub-regional polities preceding the rise of the Xiongnu state during the late first millennium BCE.
\end{abstract}

Social Evolution \& History, Vol. 18 No. 2, September 2019 55-72

(C) 2019 'Uchitel' Publishing House

DOI: $10.30884 / \mathrm{seh} / 2019.02 .03$ 


\section{INTRODUCTION}

Before addressing the major issue of this journal volume - that of pastoral nomads and their expressions of what archaeologists refer to as 'complexity,' a little more detail about that concept is needed. Presently there is no standard definition of complexity among social scientists. This encourages creativity and innovation and at the same time a level of ambiguity that probably only archaeologists are content to accept given the numerous uncertainties that we habitually work with. Despite this lack of a unified definition, 'complexity' has become a guiding concept by which archaeologists study processes of organizational change over time. 'Organization' in this case refers to arrays of human relationships and how these both derive from and format social, political, and cultural meanings and patterns. Archaeologists study shifts in these arrays over long trajectories, shorter histories, and micro-events and seek to understand how and why such transformations occur and how socio-cultural residuals from past transformations might shape the forthcoming sequences of change.

All human societies are complex because they participate in these processes of transformation equally but, in doing so, they demonstrate a fascinating range of variability reflected both within societies over time and between different societies. This diversity is sometimes partitioned into less-complex and more-complex categories based on political and economic diagnostics such as centralization, social hierarchy, specialization, etc. although the focus on these traits alone fails to reveal the underlying processes at play behind such organizational variation. So-called 'more complex' societies first began to emerge at a specific time interval in human history (early to mid-Holocene) and were rooted in new group formation processes emphasizing integration. The resulting larger groups were often associated with the methods of identity construction, forms of social differentiation, and ways of experiencing social scale that were novel to human experience. Likewise, these newly invented larger social groups also broke down over time through de-integration and this likely represented a novel kind of transformation as well. Therefore, an important social aspect of organizational complexity pertains to these group dynamics involved in constructing or de-constructing larger social scales and composite groups.

Recent archaeological research on pastoral nomads of Inner Asia has documented the networking skills of mobile peoples of the Eurasian steppe due in part to their expertise in animal transportation and cultures that privilege mobility as a critical asset (Kradin 2006, 2018). Archaeologists argue that this capacity for interactive networking across space should have also promoted integrative processes among local communities (Gardner 2016; Honeychurch 2015: 213). If correct, then early on such integrative activities could have worked to consolidate small-scale com- 
munities into multi-community identity groups and these groups may have formed the framework for what some believe were political unions of the Early Iron Age (early to the mid-first millennium BC). In turn, these polities were later implicated in the formation of the first state on the Mongolian steppe, known as the Xiongnu confederation (circa the third century BC - the second century AD). This scenario for political development has been suggested as a potential model by a series of Mongolian, Russian, and Western archaeologists but it is still lacking in detail pertinent to specific locales in Mongolia and it requires a great deal of additional testing against material evidence.

If indeed consideration of complexity leads us to focus on transformations in the quality of social relationships, in social scale, and in the extent of interactive networks, then adjusting our archaeological perspective to the level of neighboring valleys in Mongolia and what transpires within and between those valleys during the late second and early first millennium $\mathrm{BC}$ provides a way to track changes in local organization relevant to the model described above. Moreover, we suggest that changes in mobile technologies associated with horse riding would have been a deciding factor in the quality of local and extralocal interaction networks which then may have facilitated social consolidation at larger social scales. A specific set of theoretical expectations have already been offered in this regard based on many seasons of regional survey and excavation in the Egiin Gol river valley of north central Mongolia (Honeychurch et al. 2009). Drawing on data for stone monuments, burials, and habitations, fieldwork at Egiin Gol suggests that during the early to mid-first millennium $\mathrm{BC}$, there occurred a consolidation that brought surrounding valley communities into a new kind of relationship, such that Egiin Gol emerged as a kind of local center.

The factors implicated in this gradual process were increased sociospatial reach facilitated by horse mobility and the formation of alliances with groups at some remove. These alliances were initially not leadershipdriven arrangements but were probably communal accords that made available information, knowledge, ceremonial practices and beliefs, herd animal exchanges, and pastoral support. As such, participation in these agreements would have encouraged groups within and around the Egiin Gol valley to draw closer together in terms of their own local interactions and perhaps to gradually manifest a more inclusive multi-valley identity which, by the Early Iron Age, did indeed involve an emerging local elite. Based on this, we would expect evidence for the synching of this process with the rise of horse mobility as well as the appearance of material culture practices in the Egiin Gol valley that reflect external practices but which do not appear in nearby valleys surrounding Egiin Gol. Recent archaeological work in the Tarvagatai Gol valley directly north and northwest of Egiin Gol provides a new dataset to evaluate these ideas 
(Burentogtokh 2017; Gardner 2016). To set the stage, we provide a brief overview of pertinent archaeological research from Mongolia to give context for the late second and early first millennium BC. We then use this larger context to situate and identify shifts in material culture patterns in the Egiin Gol and Tarvagatai valleys in order to evaluate the above model for local integration and complexity.

\section{MACRO-REGIONAL CONTEXT}

Mongolia, leading up to the turn of the second millennium BC, was a fascinating and rapidly transforming cultural setting. The periods in question are the Late Bronze Age (1400-1000 BC) and the Early Iron Age (1000/900-300 BC). During this timeframe archaeologists have provided evidence for a developed pastoral economy in northwestern Mongolia including dairying and utilization of the five main herd animals: sheep, goat, cattle, horse, and camel (Orlando 2018). To the best of our knowledge, variants of this developed pastoral economy were practiced throughout most of the eastern steppe regions. Supplementing the pastoral economy was a long tradition of hunting, fishing, and foraging but neither grain diets nor farming are evidenced in Mongolia until quite late, at circa $300 / 200$ BC. This, in and of itself, suggests a strong focus among the early communities of Mongolia on herd animal expertise, knowledge, and technologies not seen to the same extent in areas surrounding the eastern steppe (Honeychurch 2015; Chang 2018). The earliest indications so far of mobile habitation structures similar in layout and size to contemporary Mongolian gers (i.e., yurts) appeared during the Early Iron Age (Gardner and Burentogtokh 2018), indicating a cultural capacity for fully mobile lifeways.

This Bronze to Early Iron period is marked by the construction of stone monuments of various types across the northwestern and southeastern regions of Mongolia. By the Late Bronze Age, massive stone mound constructions known as khirigsuurs (circa 1400-750 BC) were built in a range of shapes and formats from the far western mountains to the east central steppes with their numbers sharply declining eastward. The anatomy and use-history of khirigsuur mounds will make up a significant amount of this study and therefore descriptions will be offered in greater detail below. Associated with khirigsuurs are deer stone steles (1200-700 BC) with inscribed deer figures and images of Karasuk style bronze tools. These stylized bronzes have been recovered from the Minusinsk valley in South Siberia to the South Gobi Desert and into Inner Mongolia and likely represent the items of significant value among steppe communities. Currently some debate exists over the social meanings of these two kinds of monumental constructions with emphasis on either elite memorialization or their use as a means to define and demark pastoral communities and their resource areas. One thing that is certain, how- 
ever, is that by $1250 / 1200 \mathrm{BC}$ a novel practice began of horse sacrifice and feasting at khirigsuur sites with the deposition of horse heads in small stone heaps surrounding each monument (Hayashi 2013: 113-115). These horse remains provide paleopathological evidence for having been harnessed for traction and possibly for riding (Taylor 2017).

In southeastern and south central Mongolia there existed a very different monumental tradition involving human burials in a prone position interred inside large platforms built from coursed stonework in various shapes (rectangular, oblong, hourglass). This burial tradition extends into the Ordos region of Inner Mongolia and has been called by a wide variety of names including shaped or figure burials, Ulaanzuukh and Tevsh burials, and the latest term, 'prone burials' (1500/1400-1000 BC) (Amartuvshin N.d.). These mortuary structures contain the full complement of herd animal remains suggestive of a developed pastoral economy and, similar to khirigsuur sites, evidence for the inclusion of horse remains. Other burial furniture is highly variable but can include worked stone beads, gold and Karasuk style bronze items, ground stone artifacts, and red coarse ware pottery. At approximately $1000 \mathrm{BC}$, prone burial mortuary practices transitioned to a more standardized burial format known as the slab burial tradition $(1000-300 \mathrm{BC})$ which emerged in the east and gradually appeared in central and west-central Mongolia as well. Again, the social understandings of these mortuary features is controversial and while prone burials have so far received little attention, slab burial practices have been extensively studied and provide stronger evidence for status-based activities and funerary expressions of social differentiation. Although habitations are still under-emphasized in Mongolian archaeology, survey and excavation results suggest that this entire period is characterized by pastoral landscapes and regular movements between seasonal campsites (Burentogtokh 2017).

Beyond the Mongolian plateau at this time are cultural regions that have had long histories of exchange and contact with steppe communities. The mountain corridors along the Altai and the Tengri Tagh connected the regions from Minusinsk to Xinjiang and eastern Kazakhstan to western Mongolia. These geographical networks played a vital role in the transmission of bronze metallurgy, wheat, barley, and millet cultigens, wagon and chariot technologies, domestic horses and innovations in horse breeding, traction, and riding techniques (Jia et al. 2009). Similar corridors of contact existed between central and east central Mongolia and major regions within Inner Mongolia such as the Ordos Loop and the northern Dalan Khar Mountains where concentrations of prone burial cemeteries have been discovered (Ma 2017). In fact, the recent discoveries and dating of major fortified centers from western Xinjiang to Chifeng including the Bortala Valley hillforts (Jia et al. 2017), Shimao (Guo and Sun 2017), and Sanzuodian (Shelach et al. 2011) demonstrate the signifi- 
cance of these steppe interaction spheres as early as the late third and early second millennium $\mathrm{BC}$. The evidence that these zones of interaction continued to be of major importance throughout the second and first millennium $\mathrm{BC}$ is attested by the appearance of steppe technologies and resources in elite contexts of Erlitou through Western Zhou political periods of Central Plain China (Rawson 2017). This includes the adoption of bronze technology and artifact forms, chariot use for political display and warfare, and an ever-present emphasis on the horse as an animal of elite distinction, prestige, and wealth.

Considering Late Bronze to Early Iron Age Mongolia in the context of this macro-regional perspective reveals a very general but notable pattern. Against a background of common pastoral lifeways with variable adaptations suited to local environments, there are core differences in ceremonial, mortuary, and monumental traditions between northwest and southeast Mongolia. These differences are represented by the khirigsuur-deer stone complexes dominant in the west and northwest and by the prone burials and slab burial traditions in the east and southeast (Volkov 1967). Over time, these regional variants show substantial overlap due to interaction in the form of 'down-the-line' alliance networks, increased horse mobility, and extra-regional demand for steppe products and expertise. The ostensible 'pivot' of this distribution is central Mongolia where we would expect evidence for participation in each geographic tradition to appear at different times and in different sequences of introduction. The Egiin Gol and Tarvagatai valleys, located in the northcentral forest-steppe of Mongolia, should therefore provide an ideal place to study the proposed relationship between local community integration and external network building as mobility regimes transformed at circa $1000 \mathrm{BC}$.

\section{MONUMENTS, INTERACTION, AND TWIN VALLEYS}

The two river valleys in question are both situated within the extensive Selenge and Egiin Gol river drainages not far above the confluence of these two rivers. What we refer to here as the Egiin Gol valley is actually the lowermost portion of the Egiin Gol river comprising the northwestsoutheast trending main river valley, its terraces, and several tributaries $40 \mathrm{~km}$ above the Selenge river confluence. Directly to the north and northwest is the Tarvagatai Gol valley comprising an east-west trending valley system made up of a series of large tributary valleys and their drainages which flow into the main Tarvagatai river between 11 and 3 kilometers above its confluence with the Egiin Gol. These two valleys are topographically well-defined and enclosed regions connected by mountain passes. They are comparable in habitable area, waterways, and pastoral resources and effectively constitute two equivalent centers 
of habitation within the greater region. As such, we refer to them here as 'twin valleys.'

The different orientations of these valleys cause them to diverge toward the east with the Khantain mountain range separating the two basins at elevations of up to 2100 meters, making it necessary to exploit passes for inter-valley travel. The only pass that has been used in living memory and documented historically back to the nineteenth century is the $22 \mathrm{~km}$ long Uurgyn pass to the far northwest of the lower Egiin Gol which makes a connection to the mid-section of the Tarvagatai valley. This pass can be negotiated on foot or on horseback and represents a full day's journey or longer to travel. Although other plausible passes exist, the difference in elevation and travel time between those and the Uurgyn pass is dramatic. Likewise, movement along the course of the Egiin Gol river is hemmed in by a narrow channel constrained by high cliff sections and is not passable during the warm season, but when frozen during the winter, the river becomes a useable route of inter-valley movement.

In short, based on topography and geomorphology it would seem that the two valley areas are relatively isolated, but in fact inter-valley travel is possible and its somewhat regular practice is ethnographically attested (Burentogtokh 2017: 143-144). As such, the closeness of the relationships between households occupying these two areas in the past was a matter of social choice and allowance more so than logistics and that simple fact makes the study of inter-valley interaction particularly useful for assessing more or less integrated periods in the prehistory of the region. Since both valleys and the Uurgyn pass have been intensively surveyed, site types, locations, and the timing of pertinent activities at these sites help us to understand the process and directionality of the local spread of monumental construction practices. We begin with a comparison of khirigsuur site distributions across the Tarvagatai and Egiin Gol valleys. Khirisguur monuments consist of central mounds with circular or rectangular stone surrounds and heaped stone satellite features mostly on the east and southeast sides of the surround. Khirigsuurs appear as single features in the uppermost part of tributary valleys but are best known for large multi-feature complexes in the middle sections and entrances to tributary valleys.

\section{EARLY MONUMENT CONSTRUCTION, 1400-1200 BC}

Only a small number of complete excavations of khirigsuur sites exist for Egiin Gol and Tarvagatai and so far no radiocarbon dates have been obtained for a central khirigsuur mound in either valley. The best information for the initial construction of these monuments within the greater region comes from the Bugat valley, 46 kilometers south of Egiin Gol, where the earliest two human interments in khirigsuur mounds date to $1378 \pm 42$ and $1213 \pm 56 \mathrm{cal} \mathrm{BC}$. This range fits well with the wider chronology for khirigsuurs. These monumental sites emerged earliest 
in the western part of Mongolia and are related to similarly shaped stone mounded features without satellites called Sagsai burials ( $c a$. $1500 \mathrm{BC}$ ). We surmise that between 1400 and $1300 \mathrm{BC}$, the practice of building khirigsuurs was introduced to our twin valleys from outside regions probably located to the west. Presumably, these new practices involved selecting specific points on the landscape, then planning a major building project with the help of an assembled group that provided the labor needed to transport substantially large numbers and sizes of stones to the construction site. This was probably done using animal traction with carts or sledges and would have involved households in the immediate area who chose locations clearly marking pastoral resource zones and seasonal campsite areas (Burentogtokh 2017). Contrary to prior claims, a significant number of human interments have now been documented in khirigsuurs of this northern region to be able to say with confidence that funerary ceremonies were indeed an important part of monument construction (Littleton et al. 2012). Additionally, their placement and accumulation on the landscape came to define and assert the extent of pastoral territories that were occupied and actively in use at this time (Burentogtokh 2017).

In what exact manner the very first khirigsuurs were introduced to Egiin Gol and Tarvagatai is not yet known, however, two patterns are clear. First, across the two main valleys and their multiple tributary valleys both the locational patterning and the density per square kilometer of these sites are relatively consistent. This suggests that the functional aspect of khirigsuur building was uniform, that local understandings of khirigsuurs were consistent, and that the use of these sites in the separate valleys was redundant. Each valley community made use of khirigsuur monuments on par with their neighbors and probably did so independently of those neighboring communities. Second, a small number of khirigsuurs stand out as outliers based on their extremely large mound size and their prominent positions in the landscape. Interestingly, these sites cluster together in a single zone in the far northwest section of the Egiin Gol valley and in the central section of the Tarvagatai valley. From the perspective of Egiin Gol, this is precisely the area where three major pathways of movement join together: the first along the Egiin Gol valley on the north side of the river; the second entering into northwestern Egiin Gol from the west along Khatgachiin valley; and the third along the Uurgyn pass into the Tarvagatai valley.

Based on the radiocarbon dates available from satellite features and the assumption that central mounds must either be contemporary with or predate their satellites, these junction areas have not only the largest khirigsuurs but also the earliest khirigsuur constructions in both valleys. Taken together, the above observations indicate that potentially as early as $1400 \mathrm{BC}$, khirigusurs were introduced to this region and were gradual- 
ly adopted by distinct communities separated by local valley topography. Although interaction between Tarvagatai and northwest Egiin Gol households could not have been a daily occurrence, the focus of monument building activities in association with both sides of the Uurgyn pass argues for the importance of periodic contact between these discrete groups. As such, the earliest functions of khirigsuurs were probably related to local mortuary practice and memorialization, demarking and claiming pastoral territories, as well as places of inter-valley visitation where members of distinct communities might have joined in seasonal events (Burentogtokh 2017). Most important, however, is the clear center of activity we have pinpointed in the northwest and north-central parts of our twin valley study area. The way how this geographical center of activity changed over the coming centuries provides an indicator for shifts in local and regional interaction networks and the ways in which established groups responded.

\section{REGIONAL TRANSPORT, RITUAL, AND EXCHANGE, 1200-900 BC}

According to recent chronological analysis by Taylor et al. 2017, the period between 1250 and $1200 \mathrm{BC}$ marks a major transformation in the kinds of activities being performed at khirigsuur sites. It is clear that new khirigsuur mounds were still being constructed but in addition to the central mounds and circular or rectangular surrounds, small stone mounds with horse head interments became a standard practice at this time - both at newly constructed khirigsuurs and at older pre-existing sites. In fact, the bulk of evidence for activities at khirigsuur sites comes from the analysis of these smaller and more manageable satellite features containing horse skulls and vertebrae as well as very occasional artifact finds. Excavation, dating, and intensive analysis of satellite features have yielded a wealth of information on the emergence of horse-focused feasting, ritual practices, and horse use for transport. The best interpretation of this regionwide interest in horses is that after a period of experimentation with various forms of horse-based transport, including chariot use and what might be described as unsecured or 'athletic' riding (cf. Drews 2004: 39-41), steppe peoples devised a set of technologies that made horse riding reliable, secure, and sustainable over longer distances.

While there is evidence for this development at circa $1000 \mathrm{BC}$ from regions around Mongolia including archaeological finds of saddles, harnesses, and numerous rock art images of riders (Honeychurch 2015: 210-11), evidence from Mongolian khirisuurs gives us the added and critical perspective from horse paleopathology. Nasal deformations apparent on horse skulls from khirigsuur satellites strongly support the idea that these horses were harnessed (Taylor 2017). Until recently, these low profile pathologies were attributed to either harnessing for traction, or for riding, 
or for both. The latest study by the Taylor group convincingly demonstrates that the harnessing pathologies on horse skulls have a clear directional orientation that would be expected if reins were controlled on the left hand side of the horse, the position in which traditional Mongol horse riders hold their reins (Taylor and Tuvshinjargal 2018). In addition, the same group has documented fairly extensive equid dentistry practices designed to make bit placement more comfortable and effective for horses. So far, the dating of the earliest horses with these kinds of evidence is at the crucial 1100 to $1000 \mathrm{BC}$ time period with the high probability that these practices were in development by the 1200 to $1100 \mathrm{BC}$ timeframe (Taylor et al. 2018).

Taken as a whole, these many indications across a broad swathe of western and north-central Mongolia strongly suggest that the appearance of new horse-based ceremonies around khirigsuur monuments emerged in conjunction with a new form of horse use and ideology. Yet another incentive towards both improvements in horse riding and the higher valuation of horses might have been horse exchange with powerful groups in Inner Mongolia. The Late Bronze Age interaction sphere evidenced by the prone burial cemeteries north of the Dalankhar Mountains clearly spanned the Gobi regions and likely was instrumental in transferring horses, horse expertise, and related technologies southwards potentially as early as $1400 \mathrm{BC}$. This process of moving horses over longer distances would have encouraged the capacity to ride and actively control horse herds as opposed to the alternative of transporting small numbers of animals by two-wheeled horse cart (i.e., chariots) (Honeychurch 2015: 209-210).

This timeframe for horse introduction explains the lack of domestic horse remains at the early Ordos settlements of Shimao and Zhukaiguo and the appearance of horses in Xicha contexts at circa 1300 BC (Liu and Chen 2012: 388). Eventually, these introduced horses would make their way from the Ordos to the Late Shang capital at Yinxu by circa 1200 to 1150 BC where they became the signature animal for uppermost elite prestige, display, and wealth. We expect that the same steppe peoples who innovated slab burial practices subsequent to the prone burial tradition continued to manage the exchange of horses into regions associated with the Western Zhou Dynasty at circa 1000 BC. In comparison to the Shang, Western Zhou elite depended even more heavily on horses and chariots as symbols of their regime and authority and, as such, the volume of horse exchange increased in a way that benefitted communities positioned in the eastern and southeastern parts of the Mongolian plateau (Wu 2013).

On the central Mongolian steppe, this newly appraised animal wealth, transport functionality, and down-the-line exchange networking likely explains the greater emphasis on alliance-creation between distant communities and the affirmation of these agreements through horse feasting and ceremonial events around prominent khirigsuur sites. Extremely large 
khirigsuurs with satellites numbering in the hundreds, each presumably with interred horse heads, have been sub-sampled and dated at sites such as the khirigsuur B10 of Tsatsyn Ereg and the Urt Bulagyn khirigsuur at Khanui Gol (Zazzo et al. 2019; Gantulga et al. 2013; Fitzhugh 2009). In both cases, horse sacrifices likely occurred within relatively compressed time spans measuring several decades and falling into the period between 1050 and $900 \mathrm{BC}$. In addition, recent isotopic analyses reveal that the respective horses at the Urt Bulagyn site were not of local origin but came from regions surrounding the Khanui valley, affirming the use of horse feasting and sacrifice in inter-area visitation and regional alliance building (Makarewicz et al. 2018). Although it is not yet widely recognized, these horse-related rituals at the largest of khirisguur sites probably set the precedent for elite sites like Arzhan 1 only a few centuries later (Hayashi 2013; Honeychurch 2015: 174-175).

\section{THE TWIN VALLEYS, MONUMENTS, AND GEOGRAPHIC REORIENTATION, 1200-750 BC}

At Egiin Gol and Tarvagatai, we can observe step by step the introduction and spread of these same practices related to horse use and ritual. Radiocarbon dates on horse skulls from khirigsuur satellites indicate that these practices first appeared around the largest khirigsuurs in the northwest section of the Egiin Gol valley at $1127 \pm 56 \mathrm{cal} \mathrm{BC}$. The next earliest dates appear at the mouth of tributary valleys along a southeastern transect down the Egiin Gol river and then gradually appear in the upper portions of tributary valleys. These rituals seem to have been consolidated among Egiin Gol groups prior to being transferred to the Tarvagatai valley where the earliest date for satellite horse remains is $965 \pm 31 \mathrm{cal} \mathrm{BC}$. This date comes from the largest khirigsuur in the central Tarvagatai valley (TAS002) directly across from the Uurgyn pass into Egiin Gol. A similar early date was obtained from a satellite at the fourth largest khirigsuur in the Tarvagatai valley about four $\mathrm{km}$ to the west (TAS-230). Based on a total of ten radiocarbon analyses from Tarvagatai khirigsuurs, satellite horse rituals were conducted in outlying parts of the main and tributary valleys over the next two centuries and were sometimes repeated at a single khirigsuur at intervals of 100 or so years. In addition, these Tarvagatai horses likewise revealed evidence of having been harnessed as was the case elsewhere (Burentogtokh 2017).

In both valleys then, the best predictors for the earliest horse sacrifices are the size of a khirigsuur site and its location relative to a major pathway of movement, most notably the Uurgyn pass linking the two major valleys. The most parsimonious way to explain the overall distribution of radiocarbon dates is by way of an initial introduction of horse sacrifice ritual into the northwest section of the Egiin Gol through the western 
Khatgachiin valley which connects to the Selenge river basin. Subsequently, these ritual practices were transferred to the Tarvagatai valley via the Uurgyn pass probably through inter-valley visitations and participation in ceremonial events. The importance of inter-community visitations in the context of these practices is underscored by oxygen isotope analyses on the horse skulls excavated from Tarvagatai satellite features. These analyses yielded diverse isotopic signatures indicating that horses had been watered at flowing as well as still water sources. Based on these results, a series of lakes up to $60 \mathrm{~km}$ distance from the valley likely represent the home ranges for some of the horses brought into the area for sacrifice and feasting events (Burentogtokh 2017).

Generally, across this region horse sacrifice and satellite building around khirigsuurs seem to have been widespread, similar in practice, and of equal distribution in both Egiin Gol and Tarvagatai. Again, this suggests that the enactment of such rituals played redundant roles for two independent valley communities that were periodically articulated by visitations, pastoral support, and probably inter-marriages. Perhaps the most notable pattern is the continued focus of activity in the northwest section of the Egiin Gol study area as the primary area for introduction and dispersal to other valleys. This is not surprising given that the practice of horse sacrifice at khirigsuur sites is most prominent in the west-central parts of Mongolia and the headwaters of both the Selenge and the Egiin Gol rivers lie within the west-central provinces of Arkhangai and Khovsgol respectively. These river basins probably facilitated the earliest contacts introducing horse rituals into the Egiin Gol valley in the first place. As would be expected, then, even though radiocarbon analysis shows that horse related khirigsuur rituals expanded fairly quickly to the far southeast tributaries of Egiin Gol, the center of satellite building, external khirigsuur elaboration, and inter-valley travel was in the northwest section of Egiin Gol (cf. Wright 2006: 268; 2007).

These geographic emphases in valley use history from circa 1400 to $900 \mathrm{BC}$ make the period beginning at $900 \mathrm{BC}$ all the more fascinating for the twin valley region. What seems to be a major reorientation of valley monumental practices and use-areas occurs with the first episode of slab burial building in the far southeastern section of the lower Egiin Gol. The two earliest slab burial sites are from the Bayan Gol tributary valley entering the Egiin Gol from the southeast and connecting through a maj or pass into the Selenge river on its eastern side. The two slab burials dated in this area were constructed at $871 \pm 41 \mathrm{cal} \mathrm{BC}$ and $868 \pm 28 \mathrm{cal} \mathrm{BC}$ and these two sites are as far from the oldest and largest khirigsuur site as is possible in the Egiin Gol valley. In addition, the spread of slab burials from this southeast center of introduction shows a remarkably linear northwestern progression up the valley according to a series of 11 radio- 
carbon dates. Notably, the tributary valleys with the earliest slab burial dates also have some of the youngest dates indicating the persistent use of the southeastern sections of the Egiin Gol as the new center for monument building during the Early Iron Age.

In comparison to the widespread and geographically redundant use of khirisguur sites, the areas of slab burial building are sharply delimited and extend only across the southeastern and central parts of Egiin Gol. In the older northwest center of khirigsuur activities, slab burials number only three out of almost 90 sites and slab burials do not exist at all in the Tarvagatai valley. This was a surprising find of our multi-year surveys and suggests that the social relationships between the Egiin Gol and Tarvagatai valleys changed radically during the early to mid-first millennium BC. During the Late Bronze Age and most of the Final Bronze Age, a long-standing pattern of replication of monumental practices within the Egiin Gol and Tarvagatai valleys suggests two distinct valley communities engaging in monument building independently. The fairly rapid intervalley transmission of these rituals from Egiin Gol to Tarvagatai argues for periodic contacts with a primary focus on the northwestern pass system. From $900 \mathrm{BC}$ onward, however, the western interaction sphere accessed via the northwestern pass system diminished in favor of a newly emerging eastern interaction sphere accessed through the southeastern pass system. This section of Egiin Gol is where we find an entirely new monumental vocabulary associated regionally with eastern and east central parts of Mongolia (Navaan 1975).

By virtue of this reorientation, and probably in reaction to external shifts in the regional context of exchange networks and elite prerogative, southeastern Egiin Gol became a center for monument building which seems to have integrated surrounding valley communities by way of participation in those new activities. In other words, households in northwestern Egiin Gol and Tarvagatai were incentivized to interact closer and more regularly with communities in southeastern Egiin Gol, the area seemingly acknowledged as the 'proper' site for the building of mortuary monuments post $900 \mathrm{BC}$. This included horse feasting and satellite interments at khirigsuurs which were carried out for the next two centuries contemporaneous with slab burial building. The latest horse head satellite in the twin valleys dates to $735 \pm 56 \mathrm{cal} \mathrm{BC}$ and after that, horse remains were exclusively interred in slab burial assemblages. Khirisguur sites, while still revered and acknowledged, increasingly became a social memory in the background of slab burial events designed to memorialize prominent individuals and their local elite lineages (Honeychurch 2015: 142-143).

Interestingly, this transformation in monument building occurred independently of major shifts in habitation patterns or in pastoral resource 
use, which in both Egiin Gol and Tarvagatai remained stable over this period. However, a large settlement with post holes, built structures, and ritual deposition of materials such as deer antler tines does appear in the new southeastern activity zone (Galdan 2015). This settlement has been extensively radiocarbon dated to the mid-first millennium $\mathrm{BC}$ and, as a fairly unique site type, probably relates to the new found status of the southeastern tributary valleys. Habitation site data also provides a way to further test our conclusion about multi-valley integration during the Early Iron Age. We conducted excavations at seasonal campsites in the Tarvagatai valley in order to determine whether common households might have evidence for increased interaction with the Egiin Gol valley as we would expect.

One campsite in particular (TAS-77) yielded important evidence for a tent-like mobile structure, a hearth, and a great deal of domestic pottery fragments all dated to circa 500/400 BC (Gardner and Burentogtokh 2018). Using neutron activation analysis (NAA) the chemical composition of these sherds was compared to contemporaneous ceramics and clays from the Egiin Gol and Tarvagatai valley. The analysis demonstrates that the Tarvagatai household occupying this particular winter campsite drew exclusively on Egiin Gol clay sources to manufacture their everyday pottery (Gardner 2016: 184-200). This result further confirms our conclusion that these two geographical areas had become much closer in terms of interaction and integration by this time. Given the emphasis on elite mortuary differentiation, the exclusivity of slab burial construction areas, and the seemingly central position of southeastern Egiin Gol within the great region, a likely interpretation is that by the Early Iron Age, formerly independent communities merged to form a new kind of political group. We would expect similar processes to have occurred in other parts of central Mongolia and suggest that these early 'local' polities likely formed the organizational foundations for the Xiongnu state during the third century BC.

\section{CONCLUDING DISCUSSION}

According to our model above, a new integrative dynamic accompanied transport technologies that allowed for greater mobility and involvement in external networks of alliance and interaction. Clearly, for both Egiin Gol and Tarvagatai, pass systems and the directional orientation of cultural practices (northwest and southeast) influenced the site types local communities were building, as well as when and where they were built. Even though the fine-grained analysis for horse riding techniques within the twin valleys is still being developed, the Mongolian regional dataset evidencing horse transport is greatly improved and articulates quite well in terms of chronology with the rise of novel horse ideologies and rituals in these two valleys. Early first millennium BC finds of horse harnessing 
equipment and rock art images of riding at Egiin Gol have been discussed elsewhere and lend support to horse riding having become more commonplace at the same time we observe major changes in monument activities (Honeychurch et al. 2009).

Perhaps most interesting is the geographic 'pivot-like' dynamic that we observe in the study area ideally positioned between regions of northwestern and southeastern monumental traditions within Mongolia. Archaeologists have hypothesized that 'central Mongolia' became 'central' precisely because of these deep time precedents of combining different cultural traditions from the east and west (Honeychurch and Amartuvshin 2011). A focus on these twin valleys demonstrates that the central pivot dynamic between southeastern and northwestern Mongolia also played out at micro-scales within localities in central Mongolia. Mobility born of pastoral nomadic experience, knowledge, and technologies made these regionally-scaled networks of communication and transfer possible. In addition, geographical shifts such as the one documented here occur more rapidly in a transportenabled environment and because of that rapidity, those positioned favorably in relation to external networks and resources had enhanced potential to become intermediaries. This clearly happened in the case of the southeastern communities within the Egiin Gol valley whose initial external contacts positioned a sub-set of households to exploit early interactions with network partners further to the south and east. This geographic and mobility dependent process of external networking instilled a potential for local social differentiation. This opportunity was certainly acted upon by Egiin Gol households in formatting an approach to elite leadership and factions typically associated with Early Iron Age politics among nomadic groups (Kradin 2018: 19-20).

Finally, we turn to the issue of complexity. We have set our focus on tracing processes of integration as an approach to complex organization and transformation among ancient Mongolian pastoralists. For the most part, our discussion avoids aspects of centralization, hierarchy, wealth, and status in favor of the explicitly social processes of group formation. But one might ask, what is 'complex' about a larger group? In other words, this new group identity is a scalar composite made up of numerous smaller social units including household groups, small tributary valley communities, and full valley communities. All of these subscales were merged into a new multi-valley social identity probably by circa 800 BC. By virtue of this novel identity, an Early Iron Age herder living in central Tarvagatai and another herder living in southeastern Egiin Gol might think of themselves as belonging to one and the same regional community. As such, daily social life had to take into account quite a bit more social information and as a result, became somewhat more complicated in terms of negotiating the relationships between these two 
herders. For example, based on the potential for an asymmetric status to be assumed by the herder living in the emergent southeastern center of Egiin Gol, perhaps that individual might have claimed some prerogative over the herder who found him or herself living in the now 'peripheral' area of Tarvagatai valley.

Complexity, in this explicitly 'social' version is not conceived of as a descriptive condition frozen in time but as a set of social relationships that are dynamic, continually inter-acted, and subject to change if not performed according to precedent and expectation (Honeychurch 2015: 34 40). In this sense, a leader is only a 'leader' because followers choose to comply and 'follow' on a more or less regular basis, day to day. We do not place emphasis on social forms (e.g., hierarchy) but on social acts (e.g., complying, entreating, or resisting) which can at times be acts neglected or, on the other hand, participated in or coercively enforced. Without formal social 'structure' per se, what is left to guide society is merely the social preconception that relationships and established 'ways of behaving' should be conformed to. Social reality is continuously subject to thousands of micro-decisions made every day as to whether each and every individual will conform to relational expectations or not.

As such, complexity is built into the enactment of social relations themselves and cannot be understood as a static structure independent of interaction. In this sense, larger composite groups produce a social environment that comprises more information, is more complicated to navigate, and is, therefore, potentially more uncertain. A larger integrated community, such as the one we document above, thus requires more energy and material investment, more thought, more symbolism, and more social ideology to sustain it on a daily basis. This harnessing of material, energy, symbols, and thought needed to negotiate and navigate a novel social environment is the very essence of social complexity. Such harnessing can be accomplished in myriad ways of which the ancient pastoral nomads of north central Mongolia have provided us with but one example.

\section{REFERENCES}

Amartuvshin, Ch. N.d. Turuulge n' kharuulsan orshuulgat bulsh. Arkheologiin sudlal. Forthcoming.

Burentogtokh, J. 2017 Pastoralists, Communities, and Monumentality during the Mongolian Bronze Age. Ph.D. Dissertation, Yale University, New Haven, CT.

Chang, C. 2018. Rethinking Prehistoric Central Asia. New York: Routledge.

Drews, R. 2004. Early Riders: The Beginnings of Mounted Warfare in Asia and Europe. London: Routledge.

Fitzhugh, W. 2009. Pre-Scythian Ceremonialism, Deer Stone Art, and Cultural Intensification in Northern Mongolia. In Hanks, B., and Linduff, K. (eds.), 
Social Complexity in Prehistoric Eurasia: Monuments, Metals, and Mobility (pp. 378-411). Cambridge: Cambridge University Press.

Galdan, G. 2015. Ertnii nuudelchdiin buuts suurin (otog)-giin sudalgaa. Arkheologiin sudlaa 35 (13): 184-197.

Gantulga, J.-O., Yeruul-Erdene, C., Magail, J., and Esin, Y. N. 2013. Khoid tamiryn khondii dekh bugan chuluun khoshoonii sudalgaany zarim ur dun. Arkheologiin sudlal 33 (6): 95-119.

Gardner, W. 2016. Early Political Complexity and Community Organization on the Mongolian Steppe. Ph.D. dissertation, Yale University, New Haven, CT.

Gardner, W., and Burentogtokh, J. 2018. Mobile Domiciles of the Eurasian Steppe: Archaeological Evidence of Possible Dwelling Space during the Early Iron Age. Journal of Field Archaeology, DOI: 10.1080/00934690.2018.1475994.

Guo, Q., and Sun, Z. 2017. The East Gate of Shimao: An Architectural Interpretation. Archaeological Research in Asia. URL: https://doi.org/10.1016/j.ara.2017.05.001.

Hayashi, T. 2013. The Beginning and the Maturity of Nomadic Powers in the Eurasian Steppes: Growing and Downsizing of Elite Tumuli. Ancient Civilizations from Scythia to Siberia 19: 105-141.

Honeychurch, W. 2015. Inner Asia and the Spatial Politics of Empire: Archaeology, Mobility, and Culture Contact. New York: Springer.

Honeychurch, W., and Amartuvshin, Ch. 2011. Timescapes from the Past: An Archaeogeography of Mongolia. In Sabloff, P. (ed.), Mapping Mongolia: Situating Mongolia in the World from Geologic Time to the Present (pp. 195219). Philadelphia: University of Pennsylvania Press.

Honeychurch, W., Wright, J., and Amartuvshin, Ch. 2009. Re-writing Monumental Landscapes as Inner Asian Political Process. In Hanks, B., and Linduff, K. (eds.), Social Complexity in Prehistoric Eurasia: Monuments, Metals, and Mobility (pp. 330-357). Cambridge: Cambridge University Press.

Jia, P., Betts, A., and Wu, X. 2009. Prehistoric Archaeology in the Zhunge'er (Junggar) Basin, Xinjiang, China. Eurasian Prehistory 6 (1-2): 167-198.

Jia, P., Betts, A., Doumani-Dupuy, P., Cong, D., and Jia, X. 2017. Bronze Age Hill Forts: New Evidence for Defensive Sites in the Western Tian Shan, China. Archaeological Research in Asia. URL: https://doi.org/10.1016/j.ara.2017.10.005.

Kradin, N. 2006. Cultural Complexity of Pastoral Nomads. World Cultures 15 (2): 171-189.

Kradin, N. 2018. Ancient Steppe Nomad Societies. In Ludden, D. (ed.), Oxford Research Encyclopedia of Asian History (pp. 1-28). Oxford: Oxford University Press.

Littleton, J., Floyd, B., Frohlich, B., Dickson, M., Amgalantogs, Ts., et al. 2012. Taphonomic Analysis of Bronze Age Burials in Mongolian Khirigsuurs. Journal of Archaeological Science 39: 3361-3370.

Liu, L., and Chen, X. 2012. The Archaeology of China: From the Late Paleolithic to the Early Bronze Age. Cambridge: Cambridge University Press.

Ma, J. 2017. The Survey of Slab Burials in the Yinshan Mountains. Eurasian Studies 5: 54-84. 
Makarewicz, C., Winter-Schuh, C., Byerly, H., and Houle, J.-L. 2018. Isotopic Evidence for Ceremonial Provisioning of Late Bronze Age Khirigsuurs with Horses from Diverse Geographic Locales. Quaternary International 476 (20): 70-81.

Navaan, D. 1975. Dornod Mongolyn khurliin ue. Ulaanbaatar: Academy of Sciences.

Orlando, L. 2018. Late Bronze Age Cultural Origins of Dairy Pastoralism in Mongolia. Proceedings of the National Academy of Sciences 115 (48): 1208312085.

Rawson, J. 2017. Shimao and Erlitou: New Perspectives on the Origins of the Bronze Industry in Central China. Antiquity 91 (355): 5.

Shelach, G., Raphael, K. and Jaffe, Y. 2011. Sanzuodian: The Structure, Function and Social Significance of the Earliest Stone Fortified Sites in China. Antiquity 85 : $11-26$.

Taylor, W. 2017. Horse Demography and Use in Bronze Age Mongolia. Quaternary International 436: 270-282.

Taylor, W., Burentogtokh, J., Lowry, K., Clark, J., Tuvshinjargal, T., and Bayarsaikhan, J. 2017. A Bayesian Chronology for Early Domestic Horse Use in the Eastern Steppe. Journal of Archaeological Science 81: 49-58.

Taylor, W., Bayarsaikhan, J., Tuvshinjargal, T., Bender, S., Tromp, M., Clark, J., Lowry, K., Houle, J.-L., Staszewski, D., Whitworth, J., Fitzhugh, W., and Boivin, N. 2018. Origins of Equine Dentistry. Proceedings of the National Academy of Sciences 115 (29): 6707-6715.

Taylor, W., and Tuvshinjargal, T. 2018. Horseback Riding, Asymmetry, and Changes to the Equine Skull: Evidence for Mounted Riding in Mongolia's Late Bronze Age. In Bartosiewicz, L., and Gál, E. (eds), Care or Neglect? Evidence of Animal Disease in Archaeology (pp. 134-154). Oxford: Oxbow Books.

Volkov, V. 1967. The Bronze and Early Iron Age in North Mongolia. Ulaanbaatar: Academy of Science. Original in Russian (Волков, В. Бронзовый и ранний железный век. Улан-Батор: Академия наук).

Wright, J. 2006. The Adoption of Pastoralism in Northeast Asia: Monumental Transformation in the Egiin Gol Valley, Mongolia. Ph.D. Dissertation, Harvard University, Cambridge, MA.

Wright, J. 2007. Organizational Principles of Khirigsuur Monuments in the Lower Egiin Gol valley, Mongolia. Journal of Anthropological Archaeology 26: $350-365$.

Wu, H.-Y.2013. Chariots in Early China: Origins, Cultural Interaction, and Identity. Oxford: BAR International Series.

Zazzo, A., Lepetz, S., Magail, J. and Gantulga, J.-O. 2019. High-Precision Dating of Ceremonial Activity around a Large Ritual Complex in Late Bronze Age Mongolia. Antiquity 93 (367): 80-98. 